\title{
The Role of Synbiotics (Commercial Product) as a Substitute for Antibiotic Growth Promotor (AGP) in the Performance and Blood Values of Cobb-strain Broilers Challenged with Salmonella enteritidis
}

\author{
J C Ajiguna ${ }^{1}$, V C Prakasita ${ }^{2}$, T E M Nahak ${ }^{1}$, C R Tabbu ${ }^{3}$, C M Santosa ${ }^{4}$ and A E T \\ H Wahyuni ${ }^{5, *}$ \\ ${ }^{1}$ Veterinary Science Study Program, Faculty of Veterinary Medicine, Universitas Gadjah Mada, Jl. Fauna No. 2, \\ Sleman, Yogyakarta, 55281, Indonesia. \\ ${ }^{2}$ Department of Biology, Faculty of Biotechnology, Duta Wacana Christian Univercity, Jl. Dr. Wahidin \\ Sudirohusodo No.5-25, Kotabaru, Gondokusuman, Yogyakarta, 55224, Indonesia \\ ${ }^{3}$ Department of Pathology, Faculty of Veterinary Medicine, Universitas Gadjah Mada, Jl. Fauna No. 2, Sleman, \\ Yogyakarta, 55281, Indonesia \\ ${ }^{4}$ Department of Clinical Pathology, Faculty of Veterinary Medicine, Universitas Gadjah Mada, Jl. Fauna No. 2, \\ Sleman, Yogyakarta, 55281, Indonesia \\ ${ }^{5}$ Department of Microbiology, Faculty of Veterinary Medicine, Universitas Gadjah Mada, Jl. Fauna No. 2, Sleman, \\ Yogyakarta, 55281, Indonesia \\ *Corresponding author. Email: wahyuni aeth@ugm.ac.id
}

\begin{abstract}
Feed is the main requirement for broilers farms. However, continuous use of AGP can cause antibiotic resistance in poultry and humans. The effectiveness of feed additives in preventing some disease agents has not been much scrutinized. Among the diseases that often arise is Salmonellosis. This study aims to inspect the role of synbiotics consisting of prebiotics and Saccharomyces sp. and Lactobacillus sp. as the probiotics (commercial product) on the performance and blood values of broilers challenged with Salmonella enteritidis. A total of 36 Cobb-strain DOCs were divided randomly into three groups of 12 with different diets. Group I was given broiler comercial feed, Group II was given comercial feed + AGP (enramycin dosage $250 \mathrm{~g} / \mathrm{ton}$ ), and Group III was given broiler comercial feed + Synbiotics (dosage $100 \mathrm{~g} / 100 \mathrm{~kg}$ ). Each of the three groups is then further divided into two groups of six, one of which is challenged with Salmonella enteritidis on day $22\left(1 \times 10^{9} \mathrm{CFU} / \mathrm{mL}\right)$ for peroral. Vaccines were then given to all groups: ND + IB on day 7, IBD on day 14, and ND booster on day 18. Blood was collected on day 21 and 35 , and body weights were taken every week until week 5 . The results of this study showed slight differences in the weight gain amongs the groups, with Group III and group II gaining slightly more weights than Group I. The groups that were challenged with Salmonella enteritidis gained less weight compared to the groups that were not challenged in all groups. No significant difference in blood values was found among the groups. Group II and Group III showed slighty better blood values compared to Grup I. It is concuded, then, that the use of synbiotics (commercial product) as feed additives can replace antibiotic growth promotor (AGP) because the results are almost the same.
\end{abstract}

Keywords: Synbiotics, AGP, Salmonella enteritidis, Broiler, Performance, Blood value

\section{INTRODUCTION}

Over the years, antibiotics have been used in the poultry industry for prophylactic and therapeutic purposes and also as a growth enhancer. The use of antibiotics as a growth promoter leaves residues in poultry products (meat and eggs). Strong evidence shows that the use of antibiotic growth promoters in animals and humans leads to the selection of resistant organisms that can cause treatment failure and human costs, including prolonged deaths and diseases associated with these failures [1]. Without a healthy 
digestive tract, a broiler will not be able to reach its potential performance. Extended villi are generally associated with superior intestinal health and increased nutrient absorption [2]. Here, some pathogenic microorganisms that commonly appear are Escherichia coli, Salmonella sp., Clostridium perfringens, and Campylobacter sputorum [3].

A promising alternative approach to the subtherapeutic use of antibiotics is the use of probiotics microorganisms [4]. Probiotics indeed exert some positive effects on broilers, such as reducing feed intake and improving FCR, presumably by maintaining the presence of beneficial microorganisms in the gastrointestinal tract (GIT) [5]. Probiotics seem to have beneficial effects on intestinal microflora balance, especially in young chicks, blood cholesterol concentration, and cancer, while some probiotics have a competitive exclusion effect on specific pathogens and help reduce the duration of diarrhea [6]. Each strain has a different mechanism of action [7]. Probiotics is important to maintain the intestinal health of animals, which can be achieved by mixing them with animal feed [8].

Microorganisms that can be used as probiotics can be classified in four ways: bacterial and non-bacterial probiotics; spore-forming and non-spore probiotics; multi-strain and single-strain probiotics; and autochthonous and allochthonous probiotics [9]. For poultry, the most commonly used bacterial species are Lactobacillus acidophilus, Lactobacillus casei, Lactobacillus helveticus, Lactobacillus lactis, Lactobacillus salivarius, Lactobacillus plantarum, Lactobacillus helveticus, Lactobacillus lactis, Lactobacillus salivarius, Lactobacillus plantarum, Streptococcus thermophiles, Enterococcus faecidium, Enterococcus faecium. and Escherichia coli [10]. Lactobacilli are normal components of healthy intestinal microflora. Various effects of lactic acid bacteria as probiotics depend on the strain, host, dose, timing, and viability of the strain $[11,12]$.

Providing Saccharomyces cerevisiae to broilers can achieve significant results, namely increased body weight and efficient feed conversion, compared to broilers not given additional yeasts. There are no negative effects on the internal organs or in the hematological features caused by the addition of Saccharomyces cerevisiae; in fact, administering Saccharomyces cerevisiae deliver benefits that are associated with sources of protein, minerals, and vitamin B complex [13]. Synbiotics is a combination of probiotics and prebiotics that can affect microflora in the gastrointestinal tract by increasing the number of substrates where probiotics bacteria, especially Bifidobacteria and Lactobacillus, grow. Consumption of synbiotics can enhance the immune system, prevent colon cancer, and other digestive tract disorders [14].
This study aims to determine how synbiotics used as feed additives affect broilers' weight gain and blood values compared to AGP and commercial feeds and determine the differences in those parameters within each group after Salmonella enteritidis infection.

\section{MATERIAL AND METHODS}

\subsection{Research Ethical Clearance Approval}

This research was approved by the Research Ethics Commission of the Faculty of Veterinary Medicine, Universitas Gadjah Mada (0038/EC-FKH/Int/2018).

\subsection{Experimental Design}

A total of 21 day-old broilers (Cobb) were maintained for 36 days. They were fed according to Cobb-strain maintenance standards and vaccinated according to the program in the field. From week 1 to week 2 (starter), the experimental animals are placed in brooders with husk mat. When the broilers were two weeks old, they were separated equally into six battery cages. Room temperature was decreased periodically from $33^{\circ} \mathrm{C}$ on day 1 to $24^{\circ} \mathrm{C}$ on day 24 . Lighting was provided for 23 hours a day from 1 to day 7 , but was decreased to 18 hours a day during the study. Relative humidity was maintained at $65-70 \%$. Each cage was equipped with ad libitum accesses to feed and drink.

Initially, experimental animals were divided into three groups based on the diet, namely Group I (commercial broiler feed), Group II (commercial broiler feed + AGP), and Group III (commercial broiler feed + synbiotics). Each of the three groups were further divided equally into two groups, namely Group A (broilers without challenge) and Group B (broilers challenged with Salmonella enteritidis). So, there are a total of six groups of six broilers, namely Group IA (commercial broiler feed without challenge), Group IB (commercial broiler feed challenged with Salmonella enteritidis), Group IIA (commercial broiler feed + AGP without challenge), Group IIB (commercial broiler feed + AGP challenged with Salmonella enteritidis), Group IIIA (commercial broiler feed + synbiotics without challenge), and Group IIIB (commercial broiler feed + synbiotics challenged with Salmonella enteritidis).

Three vaccinations were given to all chicken: first, ND + IB vaccine (live) on day 7; second, IBD vaccine (live) on day 14, and last ND Booster (killed) vaccine on day 18. Body weight gains were calculated by taking the weight of the broilers in all groups every week, that is, on day $7,14,21,28$, and 35 , and the weight gains of each group were then compared to each other. Blood samples were collected on day 21 to determine the normal blood values before the infection challenge was introduced on all groups B. Blood samples were also collected on day 35, that is, 14 days after the introduction of challenge by having each broiler in all challenge groups (B) orally take $1 \mathrm{~mL}$ of a suspension 
Table 1. Body weight gain of group A (without challenge)

\begin{tabular}{ccccccc}
\hline Group & Week 1 & Week 2 & Week 3 & Week 4 & Week 5 & Average \\
\hline IA (Commercial) & $88.50^{\mathrm{a}}$ & $308.16^{\mathrm{a}}$ & $463.00^{\mathrm{a}}$ & $401.50^{\mathrm{ab}}$ & $655.16^{\mathrm{a}}$ & $383.26^{\mathrm{a}}$ \\
IIA (Commercial + AGP) & $106.83^{\mathrm{a}}$ & $299.50^{\mathrm{a}}$ & $419.00^{\mathrm{a}}$ & $343.00^{\mathrm{a}}$ & $719.40^{\mathrm{a}}$ & $377.54^{\mathrm{a}}$ \\
IIIA (Commercial + Synbiotics) & $98.50^{\mathrm{a}}$ & $291.50^{\mathrm{a}}$ & $466.20^{\mathrm{a}}$ & $536.66^{\mathrm{b}}$ & $607.00^{\mathrm{a}}$ & $399.97^{\mathrm{a}}$ \\
Significant Level (P<0.05) & Ns & Ns & Ns & $*$ & ns & Ns \\
\hline
\end{tabular}

${ }^{a b c}$ Different superscripts on each row show significant differences $(\mathrm{P}<0.05)$

${ }^{n s}$ non significant difference

* significant difference

solution containing $1 \times 10^{9} \mathrm{CFU} / \mathrm{mL}$ of Salmonella enteritidis [15].

significant differences were found, the test would be continued with the Duncan post hoc test. The

Table 2. Body weight gain of group B (Challenged Salmonella enteritidis)

\begin{tabular}{ccccccc}
\hline Group & Week 1 & Week 2 & Week 3 & Week 4 & Week 5 & Average \\
\hline IB (Commercial) & $96.33^{\mathrm{a}}$ & $318.50^{\mathrm{a}}$ & $484.83^{\mathrm{a}}$ & $286.33^{\mathrm{a}}$ & $468.00^{\mathrm{a}}$ & $330.79^{\mathrm{a}}$ \\
IIB (Commercial + AGP) & $115.00^{\mathrm{a}}$ & $356.83^{\mathrm{b}}$ & $483.66^{\mathrm{a}}$ & $300.00^{\mathrm{a}}$ & $510.60^{\mathrm{a}}$ & $353.21^{\mathrm{a}}$ \\
IIIB (Commercial + Synbiotics) & $89.33^{\mathrm{a}}$ & $307.16^{\mathrm{a}}$ & $467.50^{\mathrm{a}}$ & $380.50^{\mathrm{a}}$ & $517.33^{\mathrm{a}}$ & $352.36^{\mathrm{a}}$ \\
Significat Level (P<0.05) & $\mathrm{Ns}$ & $*$ & ns & Ns & ns & Ns \\
\hline
\end{tabular}

${ }^{a b c}$ Different superscripts on each row show significant differences $(\mathrm{P}<0.05)$

${ }^{\mathrm{ns}}$ non significant difference

* significant difference

\subsection{Challenge Test}

Salmonella enteritidis isolates were obtained from the Center for Veterinary Research (BALITVET) with a registration number 2854/PK.350/H.5.1/12/2017. Salmonella enteritidis was tested on day 21 and the challenge test concentration was adjusted using McFarland 0.5 standard to $1 \times 10^{9} \mathrm{CFU} / \mathrm{mL}$. The solutions were then given orally to the challenge broilers, $1 \mathrm{~mL}$ each [16].

\subsection{Body Weight Gain}

Broiler body weight of each group was weighed and recorded every week, starting from the first day to the fifth week (day 35). Weekly weight gain was obtained by subtracting the newly-taken body weight by the weight taken in the previous week.

\subsection{Blood Value}

Blood samples were taken on day 21 and 35 from broilers in all groups (both A and B), using a $1 \mathrm{~mL}$ syringe through the brachial vein. Blood smears were prepared on glass objects, then put into EDTA tubes for blood value tests to obtain the erythrocyte and leukocyte count [17]. After the dry blood smears had been fixed

with methanol, they were painted with Giemsa staining for erythrocyte morphology and differential leukocytes [18].

\subsection{Data Analysis}

All data obtained were analyzed using the One-Way ANOVA test on a statistical program (SPSS 25). If any significance level used was $\mathrm{P}<0.05$.

\section{RESULT AND DISCUSSION}

The results for groups A (without challenge) can be seen in Table 1 and Figure 1. In week 1, 2, and 5. Group IIA $\left(106.83^{\mathrm{a}}, 299.50^{\mathrm{a}}, 719.40^{\mathrm{a}}\right)$ had a higher average weight gain than Group IA $\left(88.50^{\mathrm{a}}, 308.16^{\mathrm{a}}, 655.16^{\mathrm{a}}\right)$ and Group IIIA $\left(98.50^{\mathrm{a}}, 291.50^{\mathrm{a}}, 607.00^{\mathrm{a}}\right)$ groups, but the difference was not significant $(\mathrm{P}>0.05)$. In week 3 , Group IIIA (466.20) had a higher average weight gain than Group IA $\left(463.00^{\mathrm{a}}\right)$ and Group IIA $\left(419.00^{\mathrm{a}}\right)$, but the difference was also not significant $(\mathrm{P}>0.05)$. In week 4 , however, Group IIIA $\left(536.66^{\mathrm{b}}\right)$ had a higher average weight gain than Group IA $\left(401.50^{\mathrm{ab}}\right)$ and Group IIA $\left(343.00^{\mathrm{a}}\right)$ with significant differences $(\mathrm{P}<0.05)$. Among all groups A, Group IIIA (399.96 ${ }^{\mathrm{a}}$ ) had a higher average weekly weight gain than Group IA $\left(383.26^{\mathrm{a}}\right)$ and IIA $\left(377.55^{\mathrm{a}}\right)$, but the differences were not significant $(\mathrm{P}>0.05)$.

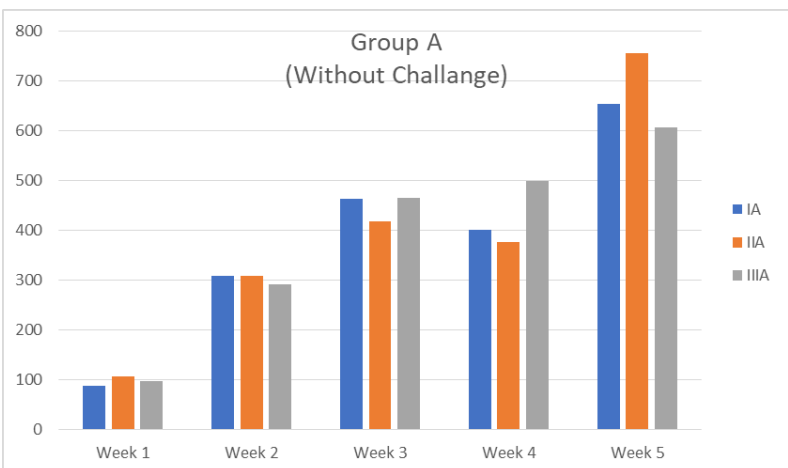

Figure 1. Body Weight Gain of group A (without challenge) 
The results for groups B (challenged with Salmonella enteritidis) are seen in Table 2 and Figure 2. In week 1 and 2, Group IIB $\left(115.00^{\mathrm{a}}, 356.83^{\mathrm{b}}\right)$ had a higher average weight gain than Group IB (96.33 $\left.318.50^{\mathrm{a}}\right)$ and Group IIIB $\left(89.33^{\mathrm{a}}, 307.16^{\mathrm{a}}\right)$. The differences were not significant in week $1(\mathrm{P}>0.05)$, but were significant in week $2(\mathrm{P}<0.05)$. In week 3 , Group IB $\left(484.83^{\mathrm{a}}\right)$ had a higher average weight gain than Group IIB (483.66 ${ }^{\mathrm{a}}$ ) and Group IIIB $\left(467.50^{\mathrm{a}}\right)$, but the differences were not significant $(\mathrm{P}>0.05)$. Finally, in week 4 and 5, Group IIIB $\left(380.50^{\mathrm{a}}, 517.33^{\mathrm{a}}\right)$ had a higher average weight gain than Group IB (286.33 $468.00^{\mathrm{a}}$ ) and Group IIB $\left(300.00^{\mathrm{a}}, 510.60^{\mathrm{a}}\right)$, but the differences were also not significant $(\mathrm{P}>0.05)$. Among all these challenge groups, IIB (353.22 $\left.2^{\mathrm{a}}\right)$ scored a higher average weekly weight gain than Group IB $\left(330.79^{\mathrm{a}}\right)$ and Group IIIB (352.36 $)$, but the differences were not significant $(\mathrm{P}>0.05)$.

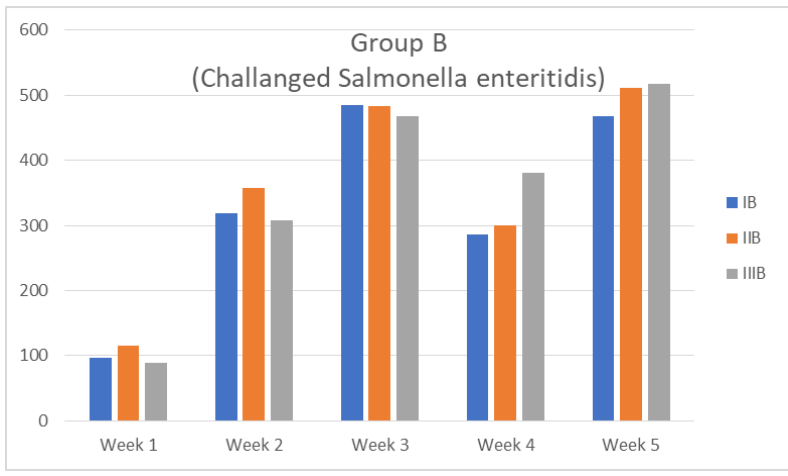

Figure 2. Body Weight Gain of group B (Challenged Salmonella enteritidis)

The results showed that the broilers that were given commercial feed with additional synbiotics and the broilers group that were given AGP had a higher body weight gain than those that were only given commercial feed, both in treatment groups A and B. This finding conforms to Nafees and Pathinathan [19], in which no significant difference was found in the final body weight between broilers given probiotics and antibiotic promotors.

Group IIA and IIIA recorded higher weight gain than Group IA, but without any significant difference. Similarly, Group IIB and Group IIIB also recorded an insignificantly higher weight gain. Hossain, et al [20] Nafees and Pathinathan [19] report that broilers fed with Bacillus subtilis, Clostridium butyricum, and Lactobacillus acidophilus endospores displayed higher body weight gains. Feed supplementation (probiotics/synbiotics) can maximize growth because it increases nutrient absorption and prevents the invasion of pathogenic bacteria such as salmonella $s p$.

Samantha, et al [21]; Mile, et al [22] explain that the increase in height and width of villi in the ileum are caused by lactic acid bacteria which can increase the production of short-chain fatty acids and reduce the production of ammonium. Short-chain fatty acids play a role in stimulating the multiplication of goblet cells in the intestinal epithelium. Epithelium villi increase in height and have wider surface for absorption of food into the bloodstream. Lactic acid bacteria are extensively used as probiotics in poultry as they are considered to be safe for the health of chicken's gut. They can also improve growth performance, carcass quality, and feed efficiency in broilers [23]. Salarmoini and Fooladi [24] state that the effectiveness of Lactobacillus cultures on broilers depends on the stress factors, ability of microorganisms to fit into the intestinal wall, antagonistic effects of microorganisms on pathogenic bacteria, and ability to competitively exclude pathogenic bacteria.

Mannan oligosaccharides (MOS) are mannose-based carbohydrates found in the Saccharomyces cerevisiae cell walls and are capable of adsorbing enteropathogens [25]. MOS have been known to improve nutrient utilization through the stimulation of specific microbial populations in the gastrointestinal tract [26]. Baurhoo et al [27] report that not only can they increase villi's height but also the number of goblet cells in all selections of the small intestine on day 24 and 34 in MOS-supplemented broilers. The main function of the goblet cells in the crypt and on the villi of intestinal tract is to produce mucus, which forms a protective layer on the villi and gut mucosa. Secreted mucus comprises mostly of mucin glycoproteins and is known to assist transportation between the lumen and the epithelial cells and is formed in the environment in which certain digestive processes could occur. The mucus also protects the intestinal lining from damage caused by gut microflora, enteropathogenic activity, digestive processes, and coarse components [28].

In groups $\mathrm{B}$, the weight gain is lower than groups $\mathrm{A}$. This can be caused by Salmonella enteritidis bacterial infection. Salmonella enteritidis can cause nutritional malabsorption, decreased growth performance, and inflammation in internal organs which lead significant economic losses in the poultry industry, in addition to contaminated poultry products and diseases carried by poultry feeds. Salmonella enteritidis has a predilection for intestinal villous epithelium, shows the presence of specific receptors, and, within 24 hours, will have reached the lamina propria and then the infiltration of inflammatory cells, thickening of the intestinal mucosa [29,30].

Some factors that influence the course of Salmonella infections include the chicken's immune response to bacterial infections, number of bacterial doses, and presence of immunosuppressive diseases [31]. Virulence factors that cause changes are modified in the form of somatic (O) and flagella (H) [32]. According to Deng, et al [33]; Saha, et al [30]; Muvhali, et al [34], Salmonella enteritidis infection in young broilers is often followed by a high mortality rate, and within a period from day 714 it is possible to be vertically transmitted. 
The average blood values of groups A (without challenge) are as seen in Table 3 . On day 21 , the average value of erythrocytes $\left(2.52 \times 10^{6}\right.$ cells $\left./ \mathrm{mm}^{3}\right)$, leukocytes $\left(12.66 \times 10^{3} \quad\right.$ cells $\left./ \mathrm{mm}^{3}\right), \quad$ heterophiles $\left(2.74 \times 10^{3}\right.$ cells $\left./ \mathrm{mm}^{3}\right)$, eosinophil $\left(0.19 \times 10^{3}\right.$ cells $\left./ \mathrm{mm}^{3}\right)$, lymphocytes $\left(8.78 \times 10^{3} \quad\right.$ cells $\left./ \mathrm{mm}^{3}\right), \quad$ monocytes $\left(3.58 \times 10^{3}\right.$ cells $\left./ \mathrm{mm}^{3}\right)$, and basophils $(0.00)$ were within monocytes $\left(4.47 \times 10^{3}\right.$ cells $\left./ \mathrm{mm}^{3}\right)$ increased over the normal ranges.

In groups A, normal blood values were recorded, with only a slight, insignificant increase in eosinophil on day 35. Meanwhile, in groups B, an increase in eosinophil and the decrease in lymphocytes were recorded on day 21 , although the differences were not

Table 3. Blood value of group A (without challenge)

\begin{tabular}{|c|c|c|c|c|c|c|c|c|c|}
\hline \multirow{2}{*}{ Blood Value } & \multicolumn{3}{|c|}{ Day 21} & \multicolumn{4}{|c|}{ Day 35} & \multirow{2}{*}{ Average } & \multirow{2}{*}{ Standard Value } \\
\hline & IA & IIA & IIIA & Average & IA & IIA & IIIA & & \\
\hline $\begin{array}{l}\text { Eritrosit } \\
\left(10^{6} \mathrm{sel} / \mathrm{mm}^{3}\right)\end{array}$ & $2.60^{\mathrm{a}}$ & $2.55^{\mathrm{a}}$ & $2.41^{\mathrm{a}}$ & 2.52 & $2.63^{\mathrm{a}}$ & $3.10^{\mathrm{b}}$ & $2.70^{\mathrm{ab}}$ & 2.81 & $2.50-3.50$ \\
\hline $\begin{array}{l}\text { Leukosit } \\
\left(10^{3} \mathrm{sel} / \mathrm{mm}^{3}\right)\end{array}$ & $13.38^{\mathrm{a}}$ & $12.46^{\mathrm{a}}$ & $12.15^{\mathrm{a}}$ & 12.66 & $12.05^{\mathrm{a}}$ & $14.45^{\mathrm{b}}$ & $13.89^{\mathrm{b}}$ & 13.28 & $12.00-30.00$ \\
\hline $\begin{array}{l}\text { Heterofil } \\
\left(10^{3} \mathrm{sel} / \mathrm{mm}^{3}\right)\end{array}$ & $2.67^{\mathrm{a}}$ & $2.82^{\mathrm{a}}$ & $2.75^{\mathrm{a}}$ & 2.74 & $3.09^{\mathrm{a}}$ & $3.70^{\mathrm{a}}$ & $3.65^{\mathrm{a}}$ & 3.48 & $2.20-6.90$ \\
\hline $\begin{array}{l}\text { Eosinofil } \\
\left(10^{3} \mathrm{sel} / \mathrm{mm}^{3}\right)\end{array}$ & $0.21^{\mathrm{a}}$ & $0.20^{\mathrm{a}}$ & $0.16^{\mathrm{a}}$ & 0.19 & $0.22^{\mathrm{a}}$ & $0.33^{\mathrm{b}}$ & $0.28^{\mathrm{b}}$ & 0.27 & $0-0.30$ \\
\hline $\begin{array}{l}\text { Limfosit } \\
\left(10^{3} \mathrm{sel} / \mathrm{mm}^{3}\right)\end{array}$ & $9.45^{\mathrm{b}}$ & $7.05^{\mathrm{a}}$ & $9.86^{\mathrm{b}}$ & 8.78 & $8.30^{\mathrm{a}}$ & $9.50^{\mathrm{c}}$ & $8.94^{\mathrm{b}}$ & 8.91 & $7.00-17.50$ \\
\hline $\begin{array}{l}\text { Monosit } \\
\left(10^{3} \mathrm{sel} / \mathrm{mm}^{3}\right)\end{array}$ & $3.38^{\mathrm{a}}$ & $3.98^{a}$ & $3.39^{\mathrm{a}}$ & 3.58 & $1.08^{\mathrm{a}}$ & $1.31^{\mathrm{b}}$ & $1.23^{\mathrm{b}}$ & 1.20 & $0.50-4.10$ \\
\hline $\begin{array}{l}\text { Basofil } \\
\left(10^{3} \mathrm{sel} / \mathrm{mm}^{3}\right)\end{array}$ & $0.00^{\mathrm{a}}$ & $0.00^{\mathrm{a}}$ & $0.00^{\mathrm{a}}$ & 0.00 & $0.00^{\mathrm{a}}$ & $0.00^{\mathrm{a}}$ & $0.00^{\mathrm{a}}$ & 0.00 & Rarely \\
\hline
\end{tabular}

${ }^{a b c}$ Different superscripts on each row show significant differences $(\mathrm{P}<0.05)$

the normal ranges. On day 35 , the eosinophil $\left(0.36 \times 10^{3}\right.$ cells $\left./ \mathrm{mm}^{3}\right)$ increased to slightly above the normal range $\left(0-0.30 \times 10^{3} \quad\right.$ cells $\left./ \mathrm{mm}^{3}\right)$, while the erythrocytes $\left(2.81 \times 10^{6}\right.$ cells $\left./ \mathrm{mm}^{3}\right)$, leukocytes $\left(13.28 \times 10^{3}\right.$ cells $\left./ \mathrm{mm}^{3}\right)$, heterophiles $\left(3.48 \times 10^{3} \quad\right.$ cells $\left./ \mathrm{mm}^{3}\right)$, eosinophils $\left(0.36 \times 10^{3} \quad\right.$ cells $\left./ \mathrm{mm}^{3}\right), \quad$ lymphocytes $\quad\left(7.12 \times 10^{3}\right.$ cells $\left./ \mathrm{mm}^{3}\right)$, monocytes $\left(2.59 \times 10^{3}\right.$ cells $\left./ \mathrm{mm}^{3}\right)$, and basophils (0.00) were still within the normal ranges.

The average blood value of group B (Challenged with Salmonella enteritidis) are shown in Table 4. On day 21, while the average value of eosinophils $\left(0.65 \times 10^{3}\right.$ cells $\left./ \mathrm{mm}^{3}\right)$ increased over the normal range $\left(0-0.30 \times 10^{3}\right.$ cells $\left./ \mathrm{mm}^{3}\right)$ and the lymphocytes $\left(5.09 \times 10^{3}\right.$ cells $\left./ \mathrm{mm}^{3}\right)$ decreased below the normal range (7.00$17.50 \times 10^{3}$ cells $\left./ \mathrm{mm}^{3}\right)$, the value of erythrocytes $\left(2.71 \times 10^{6}\right.$ cells $\left./ \mathrm{mm}^{3}\right)$, leukocytes $\left(12.02 \times 10^{3}\right.$ cells $\left./ \mathrm{mm}^{3}\right)$, heterophiles $\left(5.25 \times 10^{3}\right.$ cells $\left./ \mathrm{mm}^{3}\right)$, monocytes $\left(1.82 \times 10^{3}\right.$ cells $\left./ \mathrm{mm}^{3}\right)$ and basophils (0.00) were within the normal ranges. On day 35 , the value of erythrocytes $\left(2.11 \times 10^{6}\right.$ cells $/ \mathrm{mm}^{3}$ ) decreased below the normal range; lymphocytes $\left(12.19 \times 10^{3}\right.$ cells $\left./ \mathrm{mm}^{3}\right)$ and basophils $(0.00)$ were within the normal ranges; while leukocytes $\left(33.67 \times 10^{3} \quad\right.$ cells $\left./ \mathrm{mm}^{3}\right)$, heterophiles $\left(15.86 \times 10^{3}\right.$ cells $\left./ \mathrm{mm}^{3}\right)$, eosinophils $\left(0.34 \times 10^{3}\right.$ cells $\left./ \mathrm{mm}^{3}\right)$, and significant. On day 35, there was an increase in leukocytes, heterophils, eosinophils, and monocytes. Leukocytes play a role in responding to bacterial or viral infections. Therefore, a high number of leukocytes indicates that the body is fighting bacterial infections, and a very low number of leukocytes is usually associated with viral infections or disorders of the bone marrow [35].

In this research, leukocytosis occurred with an increase in the value of heterophils in the broilers challenged Salmonella enteritidis. An increase in the value of heterophils (heterophilia) is related to the function of heterophils as the first defense cells in the body that attack and eliminate microorganisms in normal response to bacterial infection by Salmonella enteritidis. Heterophilia in the broilers challenged Salmonella enteritidis can be associated with inflammatory reactions and changes in degeneration in internal organs. Heterophilia can also be driven by stress conditions, infections, physical restraints (restrain), administration of $\mathrm{ACTH}$, density of filled cages, and reduced consumption of drinking water. On the contrary, heteropenia condition can be caused by a severe bacterial infection, hemopoietic cell damage due to viral 
Table 4. Blood value of group B (challenged Salmonella enteritidis)

\begin{tabular}{|c|c|c|c|c|c|c|c|c|c|}
\hline \multirow{2}{*}{ Blood Value } & \multicolumn{3}{|c|}{ Day 21} & \multirow{2}{*}{ Average } & \multicolumn{3}{|c|}{ Day 35} & \multirow{2}{*}{ Average } & \multirow{2}{*}{ Standard Value } \\
\hline & IB & IIB & IIIB & & IB & IIB & IIIB & & \\
\hline $\begin{array}{l}\text { Eritrosit } \\
\left(10^{6} \mathrm{sel} / \mathrm{mm}^{3}\right)\end{array}$ & $2.76^{\mathrm{a}}$ & $2.53^{\mathrm{a}}$ & $2.86^{\mathrm{a}}$ & 2.71 & $1.71^{\mathrm{a}}$ & $2.33^{\mathrm{b}}$ & $2.29^{\mathrm{b}}$ & 2.11 & $2.50-3.50$ \\
\hline $\begin{array}{l}\text { Leukosit } \\
\left(10^{3} \mathrm{sel} / \mathrm{mm}^{3}\right)\end{array}$ & $13.33^{\mathrm{a}}$ & $11.65^{\mathrm{a}}$ & $11.10^{\mathrm{a}}$ & 12.02 & $37.76^{\mathrm{c}}$ & $33.27^{\mathrm{b}}$ & $29.99^{a}$ & 33.67 & $12.00-30.00$ \\
\hline $\begin{array}{l}\text { Heterofil } \\
\left(10^{3} \mathrm{sel} / \mathrm{mm}^{3}\right)\end{array}$ & $6.48^{\mathrm{a}}$ & $4.96^{\mathrm{a}}$ & $4.32^{\mathrm{a}}$ & 5.25 & $16.98^{\mathrm{a}}$ & $16.73^{\mathrm{a}}$ & $13.89^{\mathrm{a}}$ & 15.86 & $2.20-6.90$ \\
\hline $\begin{array}{l}\text { Eosinofil } \\
\left(10^{3} \mathrm{sel} / \mathrm{mm}^{3}\right)\end{array}$ & $0.97^{\mathrm{a}}$ & $0.22^{\mathrm{a}}$ & $0.77^{\mathrm{a}}$ & 0.65 & $0.62^{\mathrm{a}}$ & $0.33^{\mathrm{a}}$ & $0.09^{\mathrm{a}}$ & 0.34 & $0-0.30$ \\
\hline $\begin{array}{l}\text { Limfosit } \\
\left(10^{3} \mathrm{sel} / \mathrm{mm}^{3}\right)\end{array}$ & $3.77^{\mathrm{a}}$ & $6.79^{\mathrm{a}}$ & $4.73^{\mathrm{a}}$ & 5.09 & $15.35^{\mathrm{a}}$ & $10.53^{\mathrm{a}}$ & $10.69^{a}$ & 12.19 & $7.00-17.50$ \\
\hline $\begin{array}{l}\text { Monosit } \\
\left(10^{3} \mathrm{sel} / \mathrm{mm}^{3}\right)\end{array}$ & $1.68^{\mathrm{ab}}$ & $0.96^{\mathrm{a}}$ & $2.84^{\mathrm{b}}$ & 1.82 & $4.27^{\mathrm{a}}$ & $5.65^{\mathrm{a}}$ & $3.49^{\mathrm{a}}$ & 4.47 & $0.50-4.10$ \\
\hline $\begin{array}{l}\text { Basofil } \\
\left(10^{3} \mathrm{sel} / \mathrm{mm}^{3}\right)\end{array}$ & $0.00^{\mathrm{a}}$ & $0.00^{\mathrm{a}}$ & $0.00^{\mathrm{a}}$ & 0.00 & $0.00^{\mathrm{a}}$ & $0.00^{\mathrm{a}}$ & $0.00^{\mathrm{a}}$ & 0.00 & Rarely \\
\hline
\end{tabular}

${ }^{a b c}$ Different superscripts on each row show significant differences $(\mathrm{P}<0.05)$

infection, drug administration (cyclophosphamide, piperacillin, progesterone, doxycycline), and tumors [36,37].

In groups $\mathrm{B}, \mathrm{a}$ decrease in erythrocytes and eosinophilia was recorded on day 35. Shahid, et al [38] report that Salmonella $s p$. will cause anemia, especially

in cases of acute infection in chickens. Anemia that occurs in such conditions may also be a direct result of the increased ability of endothelial reticulum system to take modified erythrocytes. Modification of erythrocytes is related directly to lipopolysaccharide (LPS) or the outer membrane of the protein, indirectly to the induction of antibodies, or both to the number of bacteria in the tissue.

The recorded increase and decrease in the value of eosinophils were not very significant and those in many other groups were within the normal range. Moyes and Schute [39] state that eosinophils perform chemical immune functions against microorganisms, i.e. enzymatically. Eosinophil can increase due to several factors, including hypersensitivity, e.g. due to parasites, and allergies caused by noisy and dusty environmental factors. Meanwhile, decreased number of eosinophils (eosinopenia) can be caused by severe stress and corticosteroids [17].

\section{CONCLUSION}

This study aims to inspect the role of synbiotics consisting of prebiotics and Saccharomyces sp. and Lactobacillus sp. as the probiotics (commercial product) on the performance and blood values of broilers challenged with Salmonella enteritidis. From this study, it can be concluded that synbiotics can increase broiler weight gain, as seen from the blood tests, and maintain immunity. The addition of synbiotics to broiler feeds can replace the use of AGP.

\section{REFERENCES}

[1] Castanon J I 2007 History of the use of Antibiotic as Growth Promotors in European Poultry Feeds Poult. Sci. 86 2466-2471

[2] Sims M D, Dawson K A, Newman K E, Spring P and Hooge D M 2004 Effects of Dietary Mannan oligosaccharide, bacitracin methylene disalicylate, or both on the liver performance and Intestinal Microbiology of Turkeys Poult. Sci. 83 1148-1154

[3] Etikaningrum and Iwantoro S 2017 Kajian Residu Antibiotika pada Ternak Unggas di Indonesia. Jurnal Produksi dan Teknologi Hasil Peternakan $129-33$

[4] Pedroso A A, Hurley-Bacon A L, Zedek A S, Kwan T W, Jordan A P, Avellaneda G, Hofacre C L, Oakley B B, Collett S R, Maurer J J and Lee M D 2013 Can probiotics improve the environmental microbiome and resistome of commercial poultry production? Int J Environ. Res. Public Health 10 4534-59

[5] Younis T M, Amer A A, El-Mogazy G M and Kewan A M 2016 Efficacy of Antibiotic Growth Promotors (AGP) Alternatives Suplementation in the Diet on Broiler Performance, Intestinal, 
Morphology and Cecal Microbia Egypt Poult. Sci. 36 425-447

[6] Marteau P R, De Vresa M, Cellier C J and Schrezennier J 2001 Protection from Gastrointestinal Disease with the use of Probotics Am. J. Clin. Nutr. 73 430S-436S

[7] Lodemann U 2010 Effects of Probiotics on Intestinal Transport and Epithelial Barrier Function in: Bioactive Foods in Promoting Health: Probiotics and Prebiotics. (Waltham: Academic Press) p 303

[8] Choct M 2009 Managing Gut Health through

Nutrition British Poultry Science 50 9-15

[9] FAO[Food and Agriculture Organization of the United Nations] 2016 Probiotics in Animal Nutrition - Production, Impact and Regulation by Yadav S B, Athol V K, Peter J D and Wayne L B Editor Harinder P S, Makkar FAO Animal Production and Health Paper No 179 Rome

[10] Otutumi L K, Gois M B, de Moraes Garcia E R and Loddi M M 2012 Variations on the Efficacy of Probiotic in Poultry In E Rigobelo (ed) Probiotics in Animals Rijeka Croatia In. Tech Publizer

[11] Massens C B, Van Holten-Neelen C, Black F, Den Glashouwer M J and Claasen E 2000 Strain Dependent Induction of Cytokine Profiles in the Gut by Orally Administrered Lactobacillus Strain Vaccine 18 2613-2623

[12] Isolauri E, Sutas Y, Kankaanpaa P, Arvilommi H and Salmineen S 2001 Probiotics Effects on Immunity Am J. Clin. Nutr. 71 444S-450S

[13] Shareef A M and Al-Dabbagh A S A 2009 Effect of probiotic (Saccharomyces cerevisiae) on performance of broiler chicks Iraqi Journal of Veterinary Science I 23-29

[14] Roller M, Rechkemmer G and Watzl B 2003 Prebiotic inulin enriched with Oligofructose in combination with the probiotics Lactobacillus rhamnosus and Bifidobacterium lactis modulates intestinal immune function in rats J. Nutr. 23 154-156

[15] Dina M W, Shibat El-hamd, Hams and Ahmed M 2016 Effect of Probiotic on Salmonella enteridis infection on broiler chickens Eygpt J.Chem. Environ. Health 2 298-314

[16] Wang W, Li Z, Han Q, Guo Y, Zhang B and D'inca R 2016 Dietary live yeast and mannanoligosaccharide supplementation attenuate intestinal inflammation and barrier dysfunction induced Escherichia coli in broilers British Journal of Nutrition 116 1878-1888

[17] Weiss D J and Wardrop K J 2010 Schalm's Veterinary Hematology 6th ed (Iowa: WileyBlackwell)

[18] Clark P, Boardman W and Raidal S 2009 Atlas of Clinical Avian Hematology (United Kingdom: Blackwell Publishing)

[19] Nafees M S M and Pathinathan M 2018 Effect of Dietary Supplementation of Lactobacillus and
Streptococci Cultures on the Permofmance of Broiler Chickens DOI: http://doi.org/10.4038/agrieast.vIIi2.38 34-40

[20] Hossain M M, Begum M and Kim I H 2015 Effect of Bacillus subtilis, Clostridium butyricum and Lactobacillus acidophilus endospores on Growth Performance, Nutrient Digestibility, Meat Quality, Relative Organ weight, Microbial Shedding and Excreta Noxous Gas Emission in Broilers Veterinarni Medicina 60 77-86

[21] Samantha S, Haldar S and Ghosh T K 2010 Comparative efficacy of and organic acid blend and bacitracin methylene disalicylate as growth promoters in broiler chickens: Effects on performance, gut histology, and small intestinal milieu Vet. Med. Int. 64 51-50

[22] Mile R D, Butcher G D, Henry P R and Littell R C 2006 Effect of antibiotic growth promoters on broiler performance, intestinal growth parameter, and quantitative morphology Journal Poultry Science 85 476-485

[23] Boostant A, Mahmoodian Fard H R, Ashayerizadeh A and Aminafshar M 2013 Growth Performance, Carcass yield and Intestinal Microflora Populatiobs of Broilers Fed Diets Containing Thepax and Yogurt Brazilian Journal of Poultry Science 15 1-6

[24] Salarmoini M and Fooladi M H 2011 Efficiency of Lactobacillus bacidophilus as Probiotic to Improve Broiler Chick Performance J. agr. Sci. Tech. 13 165-172

[25] Spring P, Wenk C, Dawson K A and Newman K E 2000 The Effects of Dietary mannan Oligosaccharides on Caecall Parameters and the Concentration of Enteric Bacteria in the Caeca of Salmonella Challanged Broiler Chicks Poult. Sci. 79 205-211

[26] Kocher A, Canolly A, Zawadzki J and Gallent D 2004 The Challenge of Finding Alternative to antibiotic growth Promotors International Society for Animal Hygiene-Saint Malo 2004 227-229.

[27] Baurhoo B, Ferket P R and Zhao X 2009 Effects of Diets containing Different Concentrations of Mannanoligosaccharide or Antibiotics on Growth Performance, Intestinal Development, Cecal and Litter Microbial Populations, and Carcass Parameters of broilers Poult. Sci. 88 2262-2272

[28] Smirnov A, Tako E, Ferket P R and Uni Z 2006 Mucin Gwnw Wxpression and Mucin Content in the Chicken Intestinal Globet cells are Affected by in vivo Feeding of Carbohydrates J. Poult. Sci. 85 669-673

[29] Riberio S A M, Bercheri J A, Orsi M, Mendonca A O and Ferrati A R 2005 Experimentaly Infection by Salmonella enterica Subsp enterica Serovar Kottbus in Day-Old Broiler Chickens Brazilian Journal of Poultry Science $1516107-$ 112 
[30] Saha A K, Sufian M A M, Im Hossain and Hossain M M 2012 Salmonellosis in Layer chicken : Phatological Features and Isolation of Bacteria from Ovaries and Inner Content of Laid Egg. DOI :10.3329/jbau.v10i1.12095

[31] Maja V, Stojanov I, Dubravka P, Kapetanove M, Orlic D and Rasic Z 2005 Salmonella enteritidis Isolation from Broiler Chicken Infected with Low Doses Acta Veteriaria (Beograd) 55 183191

[32] Shu K E, Pusparajah P, Muntalab N S, Ser H L, Chan K G and Lee L H 2015 Salmonella: A review on pathogenesis, epidemiology and antibiotic resistance. Journal Frontiers in Life Science Volume 8-Issue 3

[33] Deng S X, Cheng A C, Wang M S, Yan B, Yin N C, Cao S Y, Zhang Z H and Cao P 2008 The Pathogenesis of Salmonella enteritidis in Experimentally Infected Ducks: A Quantitative Time-Course Study using Taqman Polymerase Chain Reaction Poultry Science 87 1768-1772

[34] Muvhali M, Smith A M, Rakgantso A M and Keddy K H 2017 Infestigation of Salmonella enteritidis Outbreak in South Africa using Multilocus Variable-number Tandem-repeats Analysis, 2013-2015. BMC Infection Diseases 17661

[35] Kokosharov T 2002 Clinical and Hematological effects of Salmonella gallinarum Endotoxin in Cockerels Veterinarski ARHIV 72 269-276

[36] Guyton A C and Hall J E 2008 Buku Ajar Fisiologi Kedokteran Ed. ke-11. Irawati S, LMA Ken Ariata T, Alex S, penerjemah (Jakarta : Penerbit Buku Kedokteran EGC). Terjemahan dari: Textbook of Medical Physiology

[37] Fatouh A, Gab-Allah M S, Tantawy A A, Soufy H and Nasr S M 2014 Alterations of Blood Components in Broiler Chicks Experimentally Infected with Salmonella gallinarum Global Veterinaria 13 787-793

[38] Shahid N S, Kamil S A, Dsrzi M M, Mir M S and Bhat A 2013 Haematological and Some Biochemical Changes in Experimentaal Fowl Typhoid Infection in Broiler Chickens Comperative clinical Pathology 1 1618-5641

[39] Moyes C D and Schulte P M 2008 Principles of animal physiology $2^{\text {nd }} E d$. (NewYork: Perarson International Edition) 